Williams, H., Kirton, J. and Gondek, M. 2015. Introduction: stones in substance, space and time, in. H. Williams, J. Kirton and M. Gondek (eds) Early Medieval Stone Monuments: Materiality, Biography, Landscape. Woodbridge: Boydell and Brewer, pp. 1-34. http://www.boydellandbrewer.com/store/view/tem.asp?idProduct=14947

\title{
Introduction: Stones in Substance, Space and Time
}

\author{
Howard Williams, Joanne Kirton \& Meggen Gondek
}

A triad of research themes - materiality, biography and landscape - provide the distinctive foci and parameters of the contributions to this book. The chapters explore a range of early medieval inscribed and sculpted stone monuments from Ireland (Ní Ghrádaigh and O'Leary), Britain (Gondek, Hall, Kirton and Williams) and Scandinavia (Back Danielsson and Crouwers). The chapters together show how these themes enrich and expand the interdisciplinary study of early medieval stone monuments, in particular revealing how a range of different inscribed and sculpted stones were central to the creation and recreation of identities and memories for early medieval individuals, families, households, religious and secular communities and kingdoms.

Many narratives can be created about early medieval stone monuments (e.g. Hawkes 2003a; Orton and Wood 2007). This introduction specifically tackles early medieval stone monuments as 'memory work', material strategies by which selective remembering was orchestrated and mediated not simply by the raising of carved stone monuments but by their use, reuse, translation, reconfiguration and even destruction. This chapter then explores how the chosen themes create fresh avenues for early medieval research. Examples are considered in this introduction to illustrate the wider application and significance of the book's themes in the study of stone monuments across early medieval Britain, Ireland and Scandinavia. In doing so, we acknowledge that many of the examples and issues addressed have wider import for the investigation of early medieval stones further afield across early medieval Europe and beyond. To begin, we use two case studies - one archaeological, one historical - that together draw out the centrality and interconnections of the book's three themes. We have deliberately avoided the most familiar monuments from debates in early medieval stone sculpture - such as the interpretation of the Ruthwell and Bewcastle monuments - so as to not embroil ourselves in the minutiae of worthy debates associated with these monuments that sit outside of the current focus of enquiry (e.g. É. Ó Carragáin 1999; 2003, Orton 2003; Orton and Wood 2007).

\section{A material opening: Maen Achwyfan}

In a field in north Wales is a relic of the Viking Age: the cross known as Maen Achwyfan (Whitford F12), situated near Whitford, Flintshire (Figs 1.1 and 1.2). The sandstone freestanding cross-slab in its original base now seems to be floating without context in a ploughed field. It bears no text stating its commissioners' names, who carved it or whom it commemorates, although the place-name can be taken to mean it is a cross dedicated to a saint: 'Cwyfan's Stone' (Edwards 1999; 2013, 366-71; Griffiths 2006). However, there are multiple avenues for interpreting this striking stone monument, which probably dates from the tenth century AD. 
The cross bears abstract ornamentation and human and animal figures which have received detailed consideration by Nancy Edwards, revealing aspects of its makers' and commissioners' networks of influence and ideas, and perhaps communicating wealth, authority and, just possibly, Hiberno-Norse identity and allegiance (Edwards 1999; 2013). Most striking is the lowest panel on the broad face $C$, a seemingly naked male figure armed with an axe, spear and sword partly encircled by a serpent.

We can likewise situate the monument in relation to a cluster of Hiberno-Norse placenames and other sculpted stones and artefacts that hint at Scandinavian influence and settlement on both sides of the Dee estuary. This cross is, in turn, part of a broader Irish Sea sphere of influence and exchange showing connections with Ireland, south-west Scotland, Cumbria, Lancashire, the Isle of Man and Anglesey (Griffiths 2006; Edwards 2013, 109-10).

However, this cross is made special not simply by its ornamentation and stylistic parallels in the locality and elsewhere around the Irish Sea. Its significance derives also from the strong possibility that this early medieval monument has never been moved since it was raised. The cross appears to represent a rare instance of an early medieval stone monument still situated at, or very close to, its primary location. A plausible context for the monument can be suggested: perhaps it was originally situated beside a church or chapel now long gone, upon a boundary, and commemorating the donation of land to the church at Dyserth a few miles to the west. From the vicinity, monuments of tenth-/eleventh-century date are known: $F_{2}$ and $F_{3}$ at Dyserth and $F 8$ at Meliden (Edwards 2013, 351-6; 359-62). It is even possible that the cross was the focal point of an early medieval place of assembly serving surrounding districts (Edwards 2013, 370). Geophysical survey by David Griffiths (2006) revealed that the cross originally sat within a circular boundary, defined to the north and east by the modern roadside hedgerow but originally also encircling the cross to the west and south. Moreover, the location was not only an historic boundary but also upon an ancient route replete in monumental traces of earlier times: six Bronze Age burial mounds survive in the immediate environs. Together, these traces serve to emphasize that the monument was not always so isolated, but may have sat within a complex socio-political and ecclesiastical landscape including a concentration of ancient monuments. The cross may have been a locus suitable for social aggregation and public ceremony, not just an isolated way marker (cf. Semple 2013). In summary, the monument's fixity and landscape situation are key to its interpretation as much as its form and ornamentation.

The Maen Achwyfan cross's survival in situ, strongly supported by its early first mention in 1388 (Edwards 2013, 366), affords it a distinctive and rare biographical presence in this landscape. Indeed, the Maen Achwyfan cross might have gained new significances as its original or replenished painted surfaces faded and the stone became increasingly worn by the elements. Therefore, time marks itself upon exposed stone crosses and encourages the accrual of stories about their origins and antiquity even in the absence of oral histories or visual and textual clues.

Other tempos affect the cross too, including weather conditions, as graphically illustrated by Figure 1.1. Furthermore, possible blade-marks at the base of face $\mathrm{C}$ might represent possible weapon-related ceremonial practices at the stone at some time in its history, 
especially given that these marks are immediately below the panel bearing the depiction of the naked martial figure (as seen in Edwards 2013, 369, plate F12.3; Maldonado pers. ob., see Hall, this vol.).

The chipping off of the corners of the cross-shaft might simply represent natural erosion. However, while the wear is found at all heights of the cross-shaft it is most prominent from where the panels begin and up to the beginning of the cross-head. In other words, the chipping is not even, but is found on those surfaces which could be readily reached from ground level. In stark contrast, the edges of the entire curving circumference of the crosshead itself are intact, despite its comparable exposure to the elements (Fig. 1.2). This wear or chipping was not progressive; it seems to stop so as to respect the decoration. While prosaic explanations might be ventured, a plausible explanation is that fragments off the stone's edges were incrementally removed between faces to yield stone-chips, perhaps to serve as relics at some unknown point during the life-history of the monument.

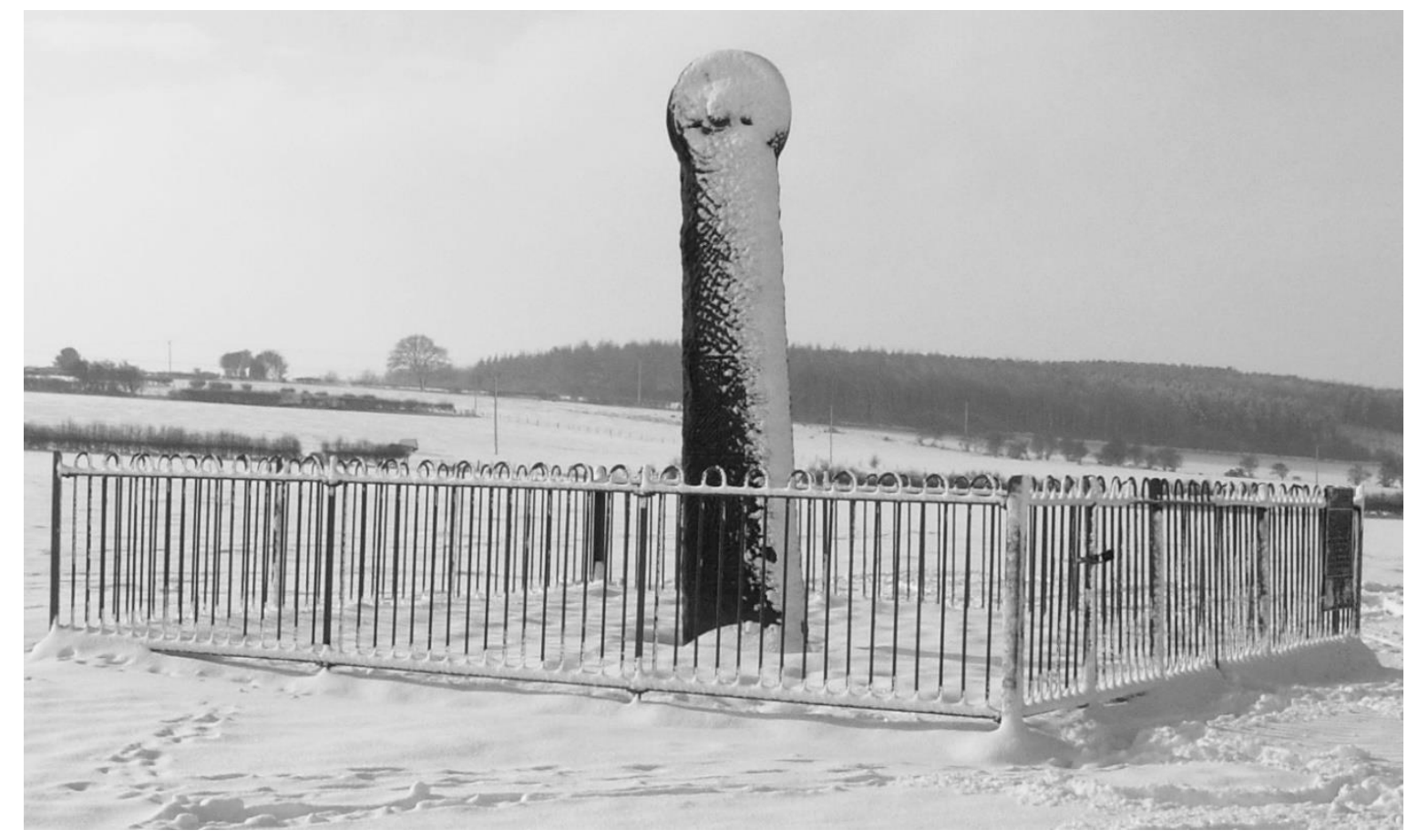

Fig. 1.1 The tenth-century cross at Maen Achwyfan, Flintshire, Wales photographed in heavy snow.

The heritage management of the site is itself part of this monument's biography. It is installed within a square of iron railings, with signs upon this fence and (more recently) beside the kissing gate into the field. Votive ribbons have been seen tied to the railings too. Afforded these twentieth- and twenty-first-century dimensions, the recent biography of the monument frames access and interpretation within a strategy of heritage management.

More can be said about the location and biography of the Maen Achwyfan cross by foregrounding both the enduring and ephemeral material properties of the stone. In terms of ephemeral dimensions, the cross was undoubtedly originally vividly painted. Furthermore, it required repainting or its surfaces would have increasingly faded. Once 
faded, the monument was open to new and different treatments and interpretations. It is possible that stones like this were initially intended for repainting on a regular (perhaps seasonal or annual) basis, or they were deliberately daubed and decked with candles and other fittings, to mark particular saints' days or the passage of the seasons (see Hawkes 2003a). There are certainly hints that this cross had now-lost fittings - perhaps glass or jewels - suggested by the four cusps around the central bosses of the cross-head on both faces $A$ and $C$ (Edwards 2013, 367). In terms of its enduring materiality, the size, shape, and material rendered it a fixed point in the landscape. Originally perhaps vividly coloured and augmented with lustrous materials, the cross was situated for all to see, to remember and possibly to touch and chip away fragments from, perhaps to facilitate healing or as votives to offer at shrines elsewhere. Likewise, although no text survives, the ornamentation and figures of humans and beasts framed an enduring narrative for the monument.

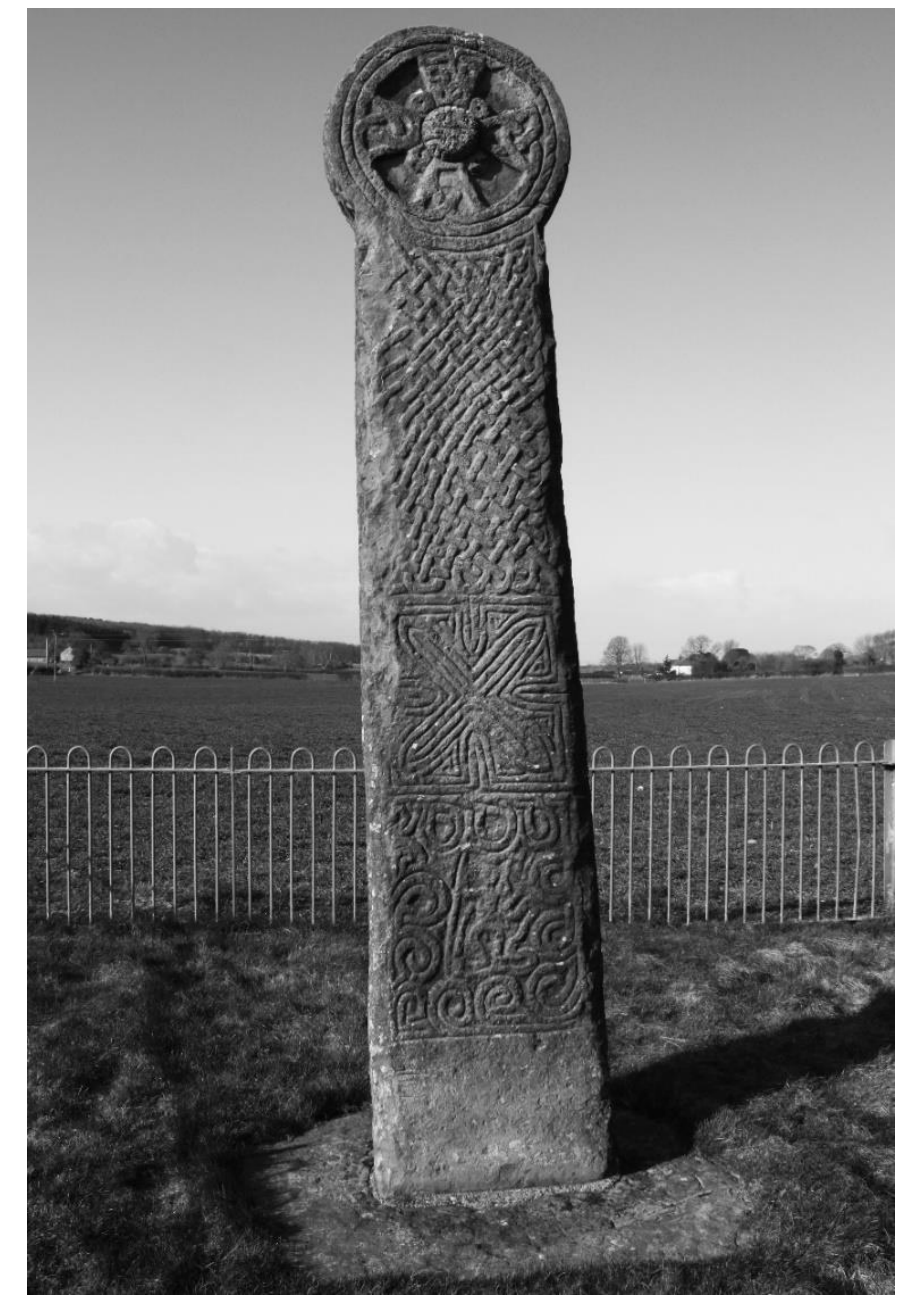

Fig. 1.2 The east side (C) of Maen Achwyfan, Flintshire, Wales.

While the Maen Achwyfan cross may be exceptional in its survival in its original location, it serves to illustrate the many ways in which we can compose narratives around monuments that extend beyond the traditional research foci of ornamentation and form. Interpreting the Maen Achwyfan cross involves considering materiality, biography and landscape together to reveal how it may have evolved in articulating faith, identities and histories of the real or imagined commissioners and makers. Furthermore, over time, and long after the 
makers were forgotten, it was retained and accrued new meanings, including a saint's dedication: Cwyfan. So the cross persisted with a saint's identity and name appended to it, eluded destruction by human or natural agency and escaped prosaic reuse. What survives, therefore, is a monument upon and around which many acts of remembering, forgetting, identity creation and negotiation were performed over the long term.

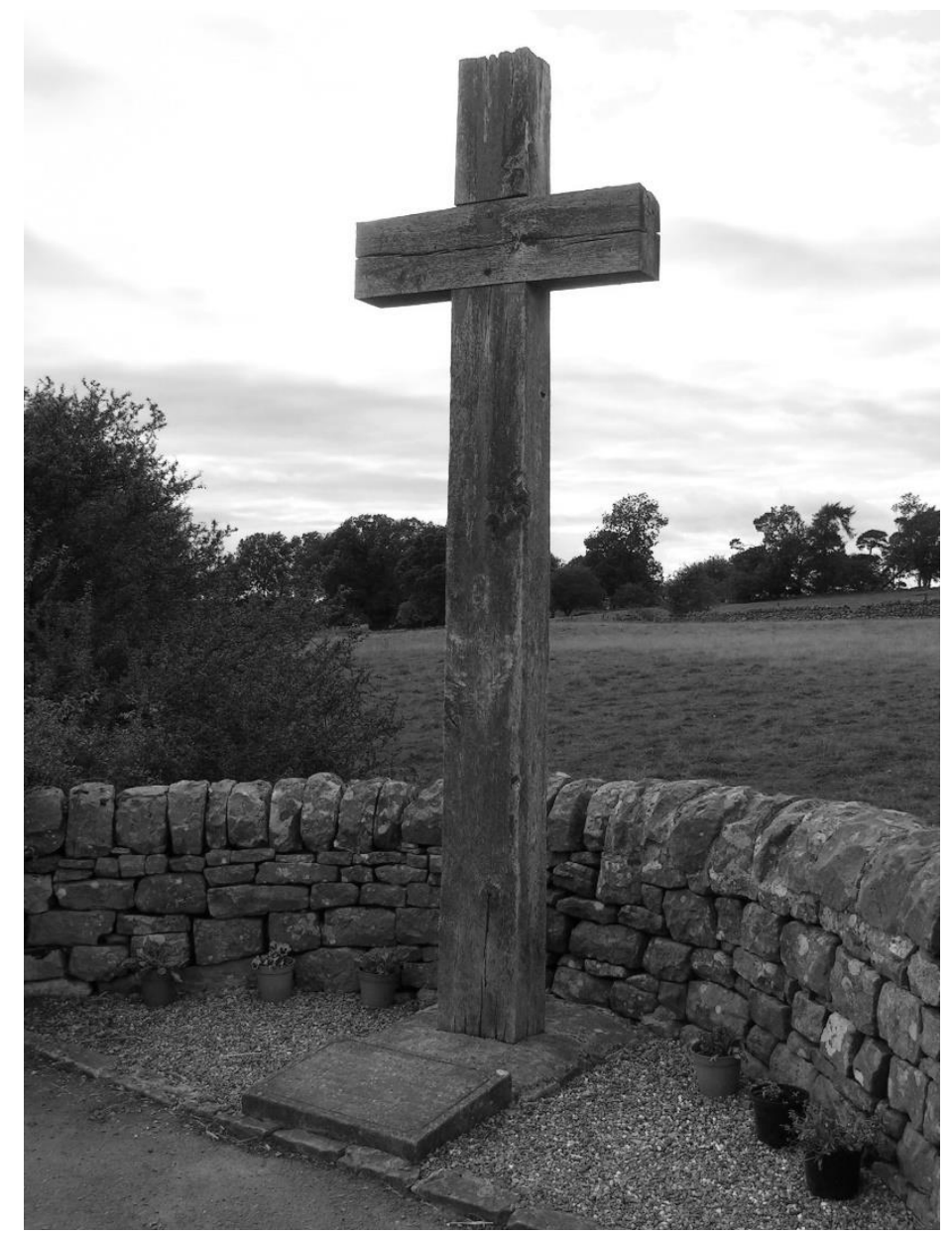

Fig. 1.3 The modern cross at Heavenfield, Northumberland.

\section{A textual exploration: Heavenfield}

A second way of introducing this book's triad of themes is to look not at a surviving early medieval monument such as Maen Acwyfan but at a monument that does not physically survive but has a key role in an important early medieval text. While this monument was one made of wood rather than stone, this in itself is useful in revealing the interplay of materials that informed the significance of early medieval stone monuments. How many wooden monuments there were is unknown, and written sources for pre-Viking England give us few clues. However, it is likely that there were many more rendered in wood than in stone in the early medieval landscape (Orton and Wood 2007, 177). Bede's account of the wooden cross at Heavenfield near Hexham, Northumberland, reveals themes complementary to those identified in the discussion of the Maen Achwyfan cross. Go there today and you will see a roadside pilgrim's wooden cross: a battle memorial citing what the original might have looked like. The site has accrued significance not through the continued presence of the same monument but through an early twentieth-century reimagining of a monument that survives only in textual form (Fig. 1.3). We have only Bede's account to tell 
Us its significance and his account is essentially a Christian origin myth for the kingdom of Northumbria (Orton and Wood 2007, 170-72; see also Hingley 2012, 36-50).

Writing his Historia Ecclesiastica (III.2), the Northumbrian monk Bede tells his readers that King Oswald of Northumbria won a great victory against his Welsh rivals at Hefenfelth (Heavenfield). The victory took place in AD 634, almost a century before Bede was writing. Bede indicates that the king's actions before the battle secured God's aid and delivered to him victory over his enemies. Oswald had hurriedly raised a wooden cross, holding it with his own hands while his troops raised earth around its base. His whole army then knelt facing the cross and prayed for victory that was then duly given by God.

The cross-raising at Heavenfield has been widely discussed, including in a study by the eminent early medieval historian lan Wood (2006, 3-4; see also Orton and Wood 2007). Wood follows Bailey (1996) in regarding Bede's account as an attempt to portray King Oswald as an English Constantine, converting ahead of a crucial battle that defined the fate of his realm. Moreover, Wood sees this story as part of a re-creation of a cult for Saint Oswald at Hexham, not necessarily a precise remembrance of the prelude to the battle. Bede's account was clearly a keystone in the origin myths of the Christian kingdom of Northumbria promoted in his day, and he claims that this was the first cross raised in Bernicia. As an eighth-century portrayal of seventh-century Christian origins for both church and kingdom, not an accurate record of what Oswald actually did, Bede's description of Oswald's cross serves to usefully illustrate this book's three themes - in particular, how the landscape, biography and materiality of monuments interconnect.

Bede emphasized the materiality of the wooden cross at Heavenfield as integral to the narrative of faith, conversion and military triumph that was wrapped about it and the cult it sustained and promulgated. Bede records that, in his time, people and animals were cured of sickness when they were sprinkled with, or drank, water in which splinters of the cross were immersed, echoing the power of the True Cross. Not only was the rough wooden monument of Bede's day the same (or reconstructed to look the same) as the monument raised before battle, but its wooden construction made it divisible, so that splinters could be distributed widely to perform healing miracles (Sherley-Price 1990, HE III. 2). The wooden monument would have required repeated maintenance and painting, or perhaps even replacing, as would any timber monument exposed to successive British winters and, as Bede suggests, regular whittling down to make relics. Such acts of reconstruction (or replacement) may have reinforced the miraculous preservation and capacity of the cross to perpetually produce relics seemingly without shrinking.

The biography of the cross was crucial to its mnemonic efficacy, even if it is unclear whether it was the cross's actual life-history or one invented shortly before Bede was writing. This biography involved it being carried to and erected on the battlefield and the unfolding sequence of miracles that led to it being 'held in great veneration' to Bede's day. Any cross of this date was itself a material citation of the crosses known to exist at the site of Christ's baptism (in wood) and the site of the Crucifixion on Golgotha (silver) (MacLean 1997, 81). A further significance of the Heavenfield cross, relating to the themes of both materiality and biography, is that its wooden composition gave it the aura of antiquity and simplicity by the eighth century, a time when crosses were increasingly being sculpted in 
stone. It also might have encouraged the cross's skeuomorphic translation and partial replication/elaboration in stone. Whether or not there was a wooden cross at Heavenfield and whether it was the first of its kind in the kingdom, as Bede asserts, by the early eighth century it was certainly present within a landscape increasingly populated with striking crosses, at least in the immediate proximity of major ecclesiastical centres (see Orton and Wood 2007, 170-71). At least some were being rendered in stone as well as wood, as, for example, Acca's cross from Hexham itself (Cramp 1984, 174-6). The primordial character of the cross may have defined both its persistent significance in the landscape and the inspiration to adapt new crosses into stone, fossilising vegetal themes in their sculpted vinescroll (MacLean 1997).

Landscape was unquestionably integral to the significance of the monument. The cross was not placed for arbitrary or prosaic reasons: whether at the site where Oswald had raised it, or an invented association with a place he was thought to have raised it, Bede's text creates a sense of place through the continuity of the cross at the battle site. It is unquestionable that the same cross placed elsewhere would not have had the same associations; place was key to its commemorative significance. Moreover, in Bede's account, the site had become a focus of an annual pilgrimage by the monks of Hexham, who had built a church on the battlefield. Hence, the monument was part of a network of sacred places and the creation of stone monuments and architectures linked by embodied ritual performance: processions through the landscape. This commemorative topography - a landscape monumentalized with crosses - is a common theme in early medieval hagiography across Britain and Ireland. Monuments might form components of such landscapes, being erected for a whole host of reasons and in a variety of places. On Iona, for example, Adomnán tells us of crosses set up at the place where the monk Ernán died and also at the spot where Columba was standing at that same moment (Sharpe 1995, 148, VC I.45). Also significant for Bede was the fact that Heavenfield was in the proximity of the truly monumental Roman (Hadrian's) Wall (Sherley-Price 1990, HE III. 3). Hence, the cross was connected to a turf and stone monument that straddled Britain, the entire width of Northumbria. This was a long-term landscape of conflict between territorial claims north and south, east and west: the Heavenfield cross was part of a landscape of memory peppered with monumental traces of the past and connected specifically with the concept of an ancient military frontier (e.g. Hingley 2012, 35-50).

In the context of this book, Bede's account of the miraculous cross foregrounds how the materiality, biography and landscape context defined the significance of the monument for an early eighth-century audience. We do not know precisely what the Heavenfield cross looked like; Bede does not convey whether the Heavenfield cross was carved with text, images or ornamentation. What is evident, however, is that details of the form and ornament of the cross, the dedicated focus of most scholarly research into early medieval monuments, was, while not irrelevant, less significant than the material, story and location for the significance afforded to it by Bede in his writing.

Given that modern scholarship has often paid limited, and sometimes no, attention to materials, life-histories and spatial contexts of early medieval monuments, just as work by archaeologists at Maen Achwyfan reveals dimensions of the monument's many dimensions of analysis beyond form and ornament, so this reading of Bede's story of the cross at 
Heavenfield offers a resounding call for a shift in the priorities of those studying early medieval stone monuments. Furthermore, it shows that early medieval texts are as much entry points into these discussions as material survivals from the early Middle Ages.

This reading of Bede reorientates our perspectives in the study of early medieval stone monuments and the contexts in which they operated. The prevailing discourse on 'style' (see Orton 2003; Hawkes 2007) persistently dominates research into early medieval sculpture despite repeated critique and reformulation, and seems completely out of kilter when seen from the perspective of Bede's account.

Early medieval scholars often attempt to reveal how many societies past and present have used monuments to commemorate, whether rough and worked, inscribed and sculpted, large and small, earth-fast or transported, architectural or free-standing. Yet precisely how and why stones operate as tools of remembrance result from complex, historical conditions that go far beyond availability and utility (see Carver 2001). The relationship between memory and monument is complicated, shaped by long-term religious and cultural values and beliefs, and influenced by monuments' architectural and/or landscape settings and by political, social and economic factors, a situation that the chapters below individually and collectively serve to demonstrate.

\section{Memory work}

Having introduced this book's three themes, let us now engage with approaches to social memory in the study of early medieval stone monuments, which is unashamedly rooted in recent developments in archaeological theory and method. Early medieval communities defined themselves through their remembered and imagined histories and mythologies. We propose that stone monuments were a varied but important mechanism for constituting, communicating and reproducing these social memories as well as holding other significances as statements projecting memory in the present and into the future. Yet the relationship between monuments and memory is highly complex in the past and the present. Key to the archaeological approach to social memory is that monuments do not 'hold' memories (see Jones 2007). Instead, they are invested with, and shed, memories in a complex and evolving process through practices. Moreover, these practices can be, in part, excavated, surveyed and analysed through archaeological techniques and methods as well as through art-historical and historical research. Memories are not simply inscribed on to monuments through text, image and ornamentation; they are incorporated into them through the ways in which the materials were selected, transported, situated, experienced and reused.

The chapters of this book collectively provide a rich range of case studies that explore, refine and extend archaeological investigations into the 'past in the past': how past societies and individuals defined themselves and mediated their histories and mythologies through material culture. Certainly, across a range of periods, archaeologists are beginning to realise that these theories and methods provide a strong foundation for considering the variability in how stones make and remake memories. The results of this research are beginning to show how stones and other materials may sometimes aspire to be permanent mnemonic records of events and/or persons, but they are frequently inherently mutable 
and contested in their mnemonic significations, subject to human and environmental action and frequently reused in novel contexts for different purposes.

The study of memory in material culture research is a growing field with many interdisciplinary dimensions and involving many different categories of monuments, from Neolithic megalithic chambered tombs to the gardens of remembrance of twenty-firstcentury crematoria. This broad, cross-period body of research on commemoration defines itself through its close attention to context and an emphasis upon what people do to commemorate, rather than static models of what people believe. The application of social memory as 'memory work' (see Van Dyke and Alcock 2003; Mills and Walker 2008) provides a valuable framework to approach the past in the past focusing on the ways in which different materials - in this case stone - are deployed and experienced. This approach proposes that social memory can be extracted from archaeological data through the theorized and contextual investigation of how routinized activities and ritual performances operate in the making and remaking of social memory through practice (e.g. see Van Dyke and Alcock 2003; Bradley 2002; Williams 2003; Yoffee 2007; Mills and Walker 2008; Mills 2009; Boric 2010; Llillios and Tasamis 2010). Hence, 'archaeologies of memory' (Van Dyke and Alcock 2003) or, more precisely, 'archaeologies of remembrance' (Williams 2003), focus less on knowledge-storage and the retrieval and reconstruction of knowable past understandings of history and memory (Bradley 2002; Jones 2007) and more on the processes by which pasts of different kinds were generated and transformed through the interaction of people with material culture, monuments and landscape: memory work.

There is now a good range of literature exploring the uses of the past in prehistoric and protohistoric/ancient societies (e.g. Alcock 2002; Bradley 2002; Jones 2007), but these themes have also become prominent in the archaeological investigation of late-historic societies, such as those of the nineteenth, twentieth and twenty-first centuries (e.g. Tarlow 1999, Saunders 2007; Williams 2011a; Burström 2012). Hence, a focus on 'memory work' is sensitive to the fact that commemorative practices, and practices of remembrance more broadly, are socially constructed and require an appreciation of contextual strategies. These strategies incorporate both remembering and forgetting, related dimensions of social memory by which communities and individuals assert, imagine, contest, negotiate and suppress pasts, presents and futures.

A series of influential applications of this theoretical approach have brought the archaeology of remembrance to early medieval studies (e.g. Bradley 1987; Driscoll 1998; 2000; Devlin 2007; Semple 1998; 2003; 2013; Williams 2001; 2006). This work has shown how a focus on memory and material culture can shed new light on early medieval communities and kingdoms and their perceptions of and aspirations relating to the past, present and future as negotiated through material culture, monuments and landscape.

However, much of the existing literature has focused on the reuse of the material past, including the collection and deployment of spolia (e.g. Eaton 2000; Stocker with Everson 1990), or on social memory within the context of mortuary practice (e.g. Williams 2006). Only a few studies have explored the wider range of other material cultures, monuments, contexts and landscapes involved in creating memories and identities, although not with detailed reference to stone sculpture in particular (most notably, see Semple 2013, 101-3). 
In this regard, carved and inscribed stone monuments are a distinctive category of early medieval material culture that held functions far beyond mortuary practice and as signals of faith and authority. As a medium, stone and its varied uses deserves closer attention as a material component of social memory. Whether by design or through accrued significance, many stone monuments, in a variety of ways, tempos and scales, became media by which worldviews and social memories were constituted, communicated and reproduced for early medieval individuals and communities (Andrén 1993; 2000; Driscoll 2000; Carver 2005).

While the various meanings and functions of early medieval stone monuments have been long debated before this book, only rarely have the commemorative significances of inscribed and sculpted stones been investigated focusing explicitly on the triad of themes that constitute this book's focus (e.g. Edwards 2001a and b; Gondek 2010; Hall et al. 2000; Williams 2006; 2007; 2011b). The study of early medieval sculpture has to dateseen few explicit engagements with, and theoretical explorations of, their commemorative significance as a creative and performative process that prehistorian Andrew Meirion Jones has dubbed technologies of remembrance (Jones 2003; 2007). This approach explores not only the design and making of sculpture but also its use and reuse, and the spatial and landscape contexts within which sculpture operates. The aim is not to claim that all early medieval stones were designed and/or became commemorative, but to explore how stones were implicated in the construction, negotiation and reproduction of recalled and imagined pasts and aspired futures for early medieval people (see Williams 2006). This book aims to foreground the hitherto under-played themes by which stone monuments were designed, or become implicated, in early medieval commemorative practice: their materialities, biographies and landscapes.

\section{Studying early medieval stone monuments}

In developing these approaches for early medieval stone monuments there are numerous challenges not only with the data but also with the complex network of disciplinary specialties that comprise the early medieval studies of inscribed and sculpted stones. Yet there are numerous reasons why carved stones are important for scholars of the early Middle Ages and are ignored by them to the severe detriment of their studies. Stone monuments are a principal surviving medium upon which less permanent and enduring forms of text, image, symbols and ornamentations can survive. Hence, inscribed and sculpted stones are a key source of historical, art-historical and archaeological data for early medieval communities and kingdoms before, during and after their conversion to the Christian faith and at shifting scales of socio-political development. Stone monuments consequently remain one of the largest data-sets of surviving material culture and their potential to inform us of the social and ideological world of their creators and audiences has not been exhausted. Insights can be gained from carved stones through the detailed analysis of stone form and ornamentation (e.g. Hawkes 2002), but also from the interplay of media, contexts and distribution (e.g. Andreeff 2012; Stocker 2000; Gondek 2006a; Griffiths 2006; Rodwell et al. 2008; Sidebottom 1994) facilitated by formal corpora such as those ongoing for England (e.g. Cramp 2006) and recently completed for Wales (e.g. Edwards 2013).

For many regions, including Scotland (e.g. Allen and Anderson 1903; Henderson and Henderson 2004), Scandinavia (e.g. Brate 1911; Brate and Wessén 1936; Sawyer 2001) and 
Ireland (e.g. Henry 1964; 1965; Harbison 1992; Kelly 1991), it could be argued that inscribed and sculpted stones have long captivated scholarly attention and charged the popular imagination because of their enduring and monumental presences in the landscape and the long tradition of antiquarian study attached to them. In other regions, despite detailed research over many decades, it could be argued that familiarity can breed indifference. This might be true of England, where sculpture has received sustained and detailed study (e.g. Cramp 1984), as well as featuring in broad syntheses on Anglo-Saxon art, culture and society (e.g. Karkov 2011; Webster 2012; Higham and Ryan 2013), yet can still find itself overlooked or relegated within many accounts and collections (e.g. Hamerow et al. 2011).

It is important to recognise that data is a challenge for answering even the most seemingly simple archaeological and art-historical questions. In Britain, for example, the demolition or restoration of churches and chapels across the country throughout the nineteenth century uncovered, in the walls and foundations of these buildings, many fragmentary examples of early medieval stone sculpture. For example, the pre-1974 counties of Derbyshire (86.3\%), Lancashire (79.2\%) and Cheshire (60.0\%) all have a relatively large proportion of surviving early medieval monuments uncovered in this manner (Kirton 2015). Consequently, much of the data-set is fragmentary, having being broken and/or recarved to suit later building needs. A chronic problem is the removal of these monuments from their original contexts, which has ensured that dating them is incredibly difficult and is usually dependent on typological sequences. The loss of original context also makes it difficult to interpret their functions and the ways in which people may have engaged with them. Their varied survival has shaped the way they have been studied, the emphasis primarily being placed on their appearance: their form, style and decoration.

The rich corpus of early medieval carved stones in northern Europe is also a challenge because of its sheer variability and the regionalism of scholarship resulting from centuries of cataloguing and specialist interdisciplinary regionalism. Hence, it is rare to find a volume such as this that tackles a wide geographic region. Regions of study (e.g. Anglo-Saxon England, Wales, Scotland, Ireland, Norway, Sweden) are often considered within the restrictions of modern political boundaries and, even within these, regionality is highly visible in terms of style, date and monument forms. With this in mind, a synthesis of the history of sculpture studies across the region within an introductory chapter is not feasible. At its most basic, the history of the study of carved stone monuments in all of these regions begins as a hybrid endeavour between art history and archaeology, usually from very early on in each region's antiquarian tradition. Cataloguing and description was occurring from the early twentieth century (e.g. Stuart 1867; Allen and Anderson 1903; Collingwood 1927; Macalister 1945; Nash-Williams 1950). This remains a key goal of scholarship, perhaps best highlighted in the sweeping objectives of the Corpus of Anglo-Saxon Sculpture, whose first volume was authored by Rosemary Cramp (1984) and which is still working its way through the counties of England.

The Corpus of Anglo-Saxon Stone Sculpture volumes, for example, have systematically recorded and synthesized the surviving architectural fragments and monuments of the early medieval period in England. This is particularly important for a data-set that is ubiquitous but largely removed from its original contexts. Providing a catalogue of these monuments, albeit one that largely focuses on the decoration and inscriptions of these 
fragments, allows scholars to quickly establish what survives, how and where it survives and how it fits with the broader assemblage.

Discussions of early medieval art usually include sculpture, but are rarely dedicated to the specific significance of this media (Karkov 2011). Most work is published in specialist corpus volumes, which usually address only specific regions and their connections with others (e.g. Edwards 2007a and b; Bailey 2011), or specialist studies of individual monuments/groups of monuments (e.g. Hawkes 2002), or in conference proceedings and edited collections (e.g. Higgitt 1986; Carver 2003). Most studies, however, focus principally on style, rather than the other components of monumental form and context (see Orton 2003; Hawkes 2007). A superb review of approaches to stone sculpture by Jane Hawkes (2003a) appeared in the edited volume Theorising Anglo-Saxon Sculpture, a volume which tackled approaches to sculpture across the disciplines of archaeology and art history. Thompson's (2003; 2004) literary perspective on the material evidence for Anglo-Saxon England also deserves note for tackling the challenge of addressing interdisciplinary questions using the Anglo-Saxon corpus. For Scandinavia, Andrén (1993; 2000) has done much to popularise and approach the theorised study of picture stones and rune-stones from an archaeological perspective. Rosemary Cramp (2010) has also recently reviewed the major developments in approach and interpretation. The sheer number of carved early medieval monuments makes syntheses beyond particular categories of monument near impossible (but see Henry 1964; 1965; Harbison 1992; Bailey 1996; Sawyer 2001). Yet paradoxically, this repeated recontextualization of sculpture reveals its mutability and potential for repeated reimagining and reinvention in new social, economic, political and religious contexts, itself a focus of the biographical approach to early medieval monuments.

\section{Materialities in stone}

It remains difficult to provide a concise definition of materiality, as it is not a methodology, per se, or a monolithic theory of material culture (cf. Ingold 2007, 2). It is, instead, an approach that prioritizes the physicality (material) of objects or sites and examines the relationships between people, objects/monuments and actions, allowing the exploration of social networks and meanings (Mills 2009, 40). The theme of materiality has been extensively explored by archaeologists particularly over the last decade (e.g. Gosden 2005) and has inspired a range of approaches to the properties and aesthetics provided by the colours, textures and multisensory qualities of stones, sediments and substances employed during artefact and monument creation and use (e.g. Cummings 2002; Jones 1999;

O'Connor and Cooney 2009; papers in O'Connor et al. 2009; Scarre 2004; Watson and Keating 1999).

These debates have already involved studies in medieval archaeology and art. For example, Giles (2007) has explored the different kinds of visuality by which space and architecture provided means of engaging with the sacred in later medieval England. Moreland (2001) has explored the interaction of word, image and material culture in the material worlds of the Middle Ages (see also Karkov 2011). Still, the attention afforded to the provenance, texture, shape and colour of stone that is prevalent in studies of prehistoric rock art and stone monumentality has not attracted the attention of scholars of early medieval stone sculpture that it deserves; studies of the materiality of stone monuments remain in their infancy. 
There are many potential applications for the materiality theme. It provides profitable insights into the significance afforded to the patina and ruinous character of prehistoric and Roman spolia reused within building programmes, and the various connotations of Romanitas that they invoked in attempts to create a Christian landscape comparable to that of Rome and Frankia (e.g. Bidwell 2010; Hawkes 2003b; Semple 2013, 133-6).

Materiality also has significance for understanding possible motives behind those cases in which stone was moved over longer distances, as revealed by the geological provenance of some sculpted stones (e.g. Jackson 2007). A good example of this is the cross from Llanbadarn Fawr 1 ( $\left.\mathrm{CD}_{4}\right)$, which, in stark contrast to most other early medieval stones from south-west Wales derived from locally available stone, seems to have been made of stone extracted by quarrying or (more probably) discovered on the surface c. $37 \mathrm{~km}$ away, and could only have been moved by human action, partly over land and then over water (Edwards 2007b; Jackson 2007, 23). In this instance, the quality of the stone, its source near the prominent mountain of Cadair Idris and its long procession to its place of sculpting and erection may have been equally central to the monument's significance in its final form, ornamentation and location.

The importance of invoking other materials in the medium of stone has been seen as pivotal to understanding the skeumorphism of crosses in Northumbria, echoing the wooden cross raised by King Oswald ahead of his victory at Heavenfield (Bailey 1996; Cramp 1984, 174-6; MacLean 1997, 81; Wood 2006, 3-4). The widespread identification of skeumorphism from wood and metal into stone, as widely discussed for Irish high crosses (Kelly 1991; see also Fisher 2001, 15), might thus be more than a display of technical and formal influence but also a key mnemonic strategy, enhancing the commemorative efficacy of the monument by connecting it to materials of other scales and settings, including specific famed monument in other locations or known from biblical and legendary narratives (T. Ó Carragáin 2007, 100). For example, Maddern (2013, 250-52) regards skeuomorphism involving a range of materials - manuscripts, wood and metal - as key to understanding the form, ornamentation and commemorative significance of pre-Viking Northumbrian name-stones.

Skevomorphism of form can be matched by skeuomorphic ornamental components upon many stone monuments, such as inhabited vinescroll and interlace carved into stones such as the eighth-century Ruthwell cross (É. Ó Carragáin 1999), or the incorporation of metal and precious stones into monuments such as the ninth-century Sandbach crosses (Hawkes $2002 ; 2003 a)$. The potential apotropaic functions of depicted artefacts, beasts as well as humanoid figures, may have been enhanced if we sometimes regard them as little to do with representations of narrative scenes but instead as apotropaic sensing beasts framing and protecting the monument itself (e.g. Hall 2012; 2013; see also Williams, this vol.). The same might apply to certain human figures depicted on crosses: to regard them as simply representations of biblical and mythological scenes overlooks the potential power for an early medieval audience of the sensing presence of living icons (see also Ní Ghrádaigh and Mullins 2013). As with other sacred artefacts bearing figural and zoomorphic art, early medieval stone monuments were truly multimedia and multi-material stone artefacts imbued with personalities and identities of the dead and/or the sacred, rendered striking 
and memorable through their deployment of colourful, shining, sonorous and tactile materials as much as through their texts and images.

This theme is significant because it extends beyond monuments dominated by figural ornamentation and even applies to those lacking figural and zoomorphic representations. These, too, may have contained powerful visual mnemonic devices through their geometric, eye-catching designs, making them both memorable and good to remember with because of, and in a manner enhanced by, their tangible and 'animated' quality. This approach helps us to better understand well-preserved memorials that lack figural art and lengthy inscriptions, such as the largely abstract ornamentation upon the Carew 1 (Pembs.) (P9) (Edwards 2007b, 303-10) and Nevern 4 (Ceredigion) (P75) crosses (Edwards 2007b, 396-401). From a materiality perspective, these stone crosses are commemorative and memorable because of their overall striking abstract patterns and the contemplative dimensions they provoked rather than their iconographic apprehension per se (e.g. Pirotte 2001).

When stones were deployed undressed or partly dressed, the natural texture, size, shape and ease of working the stone may have themselves been important components in configuring how and where the monument was deployed. This was further enhanced by the selection of colour schemes on stone monuments through the application of gesso and paint, which would have also been key elements in their materiality. Many monuments would have been painted not only to be striking landmarks but also to appear as monumental versions of sacred metalwork and holy texts. Thus the dynamic interplay between stone monuments and precious metalwork and other media (Jansson 1987, 15361; Hawkes 2003a, 17), which were enhanced by how they were lit and what season and time of day they were experienced, even on relatively simple monuments, were as important as the designs that were carved upon them. These issues have been clearly revealed by Hawkes (2003a) for the Sandbach monuments. When discussing the North cross at Sandbach, Cheshire, Hawkes has argued that many metalwork elements were incorporated into its design, rendering it 'deliberately designed as a monumental vision of the precious metalwork crosses used within the churches' (Hawkes 2003a, 27; Fig. 1.4).

This leads us to a further point about materiality: fittings and lighting could affect how the monument was experienced and read, even what time of day it was engaged with. For example, the fragmentary Tarvin cross-head was excavated in 2006 in a seventeenthcentury ditch but was originally a tenth- or eleventh-century cross, possibly situated to mark a route or boundary in relation to a nearby church (Bailey 2010, 128-9). A hole on the top of the probable upper cross-arm could have contained a metal fitting for a candleholder.

Therefore, stone monuments were inherently inspired by, and operated in conjunction with, not only their own non-stone components and fittings but also a range of other contemporary media, including textiles, leatherwork, metalwork, ivories and manuscripts. For example, it is tempting to consider how large Pictish cross-slabs such as Nigg, Shandwick and Hilton of Cadboll on the Tarbat peninsula, or the Rosmarkie cross-slabs, were networked to metalwork and manuscripts utilized in the local religious communities in their locality (e.g. Henderson and Henderson 2004, 216-25; see also Cramp 1993, 69). 


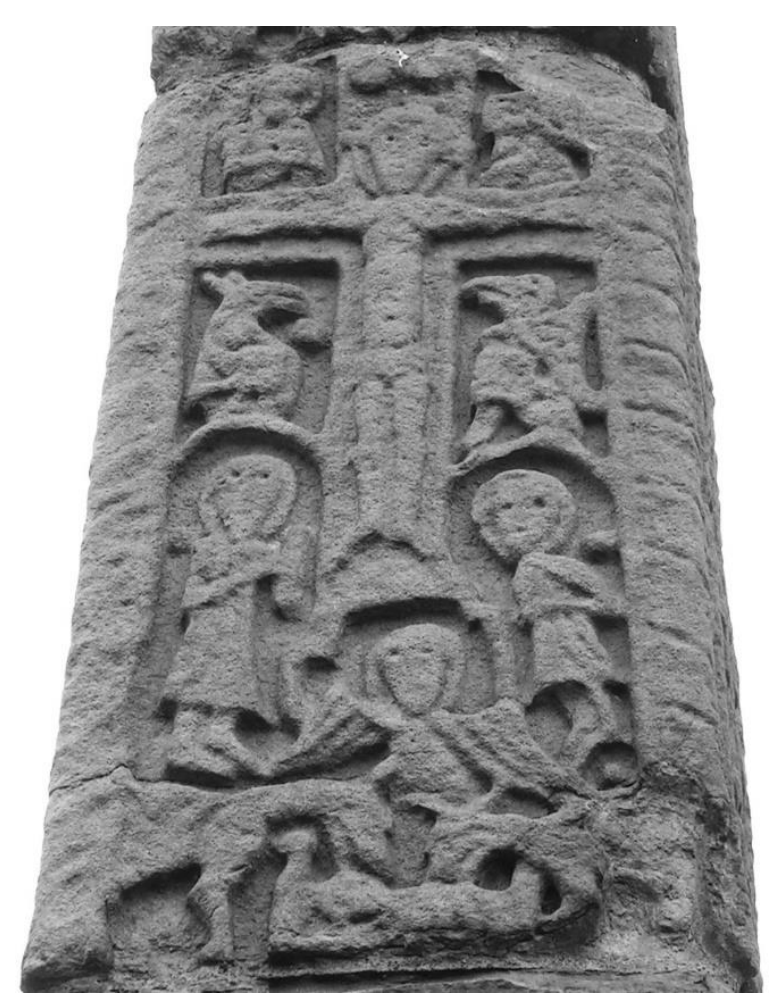

Fig. 1.4 Detail of the crucifixion scene flanked by evangelist symbols and the Nativity scene below upon stone $1 \mathrm{dA}$ (middle of broad, east face) of the north cross from Sandbach, Cheshire (after

Bailey 2010, plate 265). The pellets are skevomorphic representations of nails employed in contemporary metalwork (Hawkes 2003a, 27).

Attention to the materiality of stone monuments also allows new emphases in the study of the textual inscriptions upon them. From this perspective, the act of carving runes and letters, the depth, scale, form and arrangement of images and scripts (Higgitt 1997; 2003; Okasha 2003; Ní Ghrádaigh and Mullins 2013; e.g. Everson and Stocker 1999, 214-16) and texts' interplay with other forms of ornament (Andrén 2000) should all be taken into consideration together with the selection of words deployed in commemoration. Equally important is the context of the text and whether it was ever intended for reading in the landscape, for public utterance or for song (Devlin 2011). Conversely, texts might be made overtly obscure through the deployment of cyphers, complex shifts in direction or even by interment with the dead in anticipation of Resurrection (see Maddern 2013).

The materiality of texts is also important for considering the relationships between textual monuments. The repeated use of formulae and scripts created a shared textual identity at particular locales, an argument that might apply to the name-stones from monasteries such as Lindisfarne (Cramp 1984, 203-8) and Hartlepool (Cramp 1984, 95-101). Likewise, language and script can mark monuments out as distinctive from their counterparts and predecessors.

A number of the chapters in this book tackle the nascent theme of materiality. Kirton addresses the specific materiality of stones where ornamentation, imagery and text are eschewed in favour of clear, smooth surfaces. Back Danielsson considers rune-stones as 'things' first and foremost, not simply as backdrops to their ornamentation and runic inscriptions. Gondek is sensitive to the materiality of inscribed stones when incorporated 
into architecture. Crouwers considers the translation and representation of processional crosses upon a selection of Norwegian cross-slabs: the visual citation of physical artefacts on to stone. Meanwhile, Williams considers the architectural and skeuomorphic affordances of hogback stones as creating implied and perceptible 'solid spaces' for the dead to inhabit and pass through. Together, these chapters present new directions in the study of early medieval stone monuments and identify the wider potential for exploring the materialities of early medieval stone monuments in future research.

\section{Biography}

In contrast to the theme of materiality, exploring the 'life-histories' or biographies of artefacts, monuments and landscapes at various scales has a more established pedigree of research (e.g. Holtorf 1996; Gosden and Marshall 1999; Joy 2009; Hingley 2012). These theoretical approaches have begun to be explored in early medieval contexts, investigating the mnemonic associations afforded to old artefacts discovered or curated and subsequently treated in a variety of different ways through their circulation, display, adaptation, transformation and deployment in specific arenas (e.g. Williams 2001; 2005; 2010; Eckardt and Williams 2003; Swift 2006; Caple 2010), as well as the mythological and ancestral meanings of artefacts and assemblages with relatively short biographies but bearing antique designs and allusions (e.g. Filmer-Sankey 1996; Williams 2001; 2011C). There is also a tradition of exploring the reuse of ancient monuments within the early medieval era and the ways in which these earlier monuments, ruined buildings and their locales could become significant as foci for early medieval burial, assembly and other activities as topographies of memory (Bradley 1987; Driscoll 1998; Semple 1998; 2003; 2013; Williams 1997; 1999; Petts 2002; 2007; Sanmark and Semple 2008).

Situated between these approaches to artefacts, monuments and landscapes, and linked to each of them, a number of studies have pioneered the explicit application of the biographical approach to early medieval stone monuments. For example, Eaton (2000) explored not only the widespread reuse of Roman stone within early medieval architecture but also the inspiration these provided for new works of sculpture (see also Hawkes 2003b). Such studies reveal both how memories were created through the act of reuse and also the subsequent display and attempts to replicate these ancient works within the early Middle Ages.

St Mary-le-Wigford 6, Lincoln (Everson and Stocker 1999, 214-16; see also Higgitt 2003, 332 ) is an example of a reused Roman gabled tombstone. The stone has five lines of text within the triangle of the gable. Significantly, the text inverts convention, running from bottom to top, starting with the benefactor's name bottom left and ending at the top with the name of the saint, Mary, on a line of its own at the pinnacle of the monument. Therefore, the reader's eye ascends the text, an embodied movement that might be taken to imply spiritual ascension. In these ways, the spatial arrangement of the texts renders it efficacious as a memorial as much as do the words, while the stone is afforded a form of agency through the 'voice' attributed to it. The act of reuse is clearly significant, but in this instance so is the precise manner of reuse.

A contrasting but related approach is to explore the afterlife of early medieval stone monuments. Stocker with Everson (1990) focused on the reuse of early medieval sculpture 
particularly in later ecclesiastical structures, highlighting different practices of reuse and the potential for these to inform meanings ascribed to monuments. Cassidy (1992) explored the later history of the Ruthwell cross, Dumfriesshire, while Moreland (1999) has explored the long-term biography of the Bradbourne cross, Derbyshire, and its reinterpretation and reuse through the Middle Ages and during the Reformation, and its rehabilitation through antiquarian study to the present day. Likewise, James et al.'s (2008) study of the Hilton of Cadboll cross-slab examines the detailed history of the monument from its construction to the contesting identities and narratives claiming it in the recent past. These approaches have informed Edwards' careful reinterpretation of the ninthcentury Pillar of Eliseg and its 'afterlife', which draws upon antiquarian sources as well as the surviving monument (Edwards 2009; 2013, 322-36). Another notable study is Hall et al.'s exploration of the cultural biography of the Crieff Burgh Cross, which by close examination of the monument and its history not only suggested a primary original location and context for the cross but also charted its development as an agent in post-medieval judicial punishment (Hall et al. 2000). Likewise, Hall (2012) has explored the biographies of early medieval stones from St Madoes and Inchyra now on display in Perth Museum, which reveal their life-histories in relation to place and landscape. These cultural biographies attempt to go beyond descriptions of historical change to explore the ways in which uses and perceptions of monuments alter over time (Mytum 2003/2004, 112).

However, at the time of writing, there have been significant advances in thinking about the reuse and replication of early medieval monuments in recent centuries (e.g. Foster 2014), but fewer studies of the biographies of early medieval monuments have theorized how the life-history of the monument is related to memory work within the early medieval period (but see Hall 2012). For example, painted monuments possessed a distinctive short-term tempo, requiring repair work that perhaps operated as a key component of commemorative rituals, if the aim was for them to remain legible and discernible through multiple winters (Jansson 1987, 153-61). Such repair might have an agency of its own, as remembering and forgetting through repeated repainting transformed the appearance of the monument over years and decades, and rendered some rapidly invisible if not repainted. It is even possible that repainting allowed different iconographic readings as part of conscious efforts to reframe the relationships between scenes and panels (see Hawkes 2003a).

Once such consideration is brought centre-stage, the biographical approach can be regarded as central to understanding the use of early medieval stone monuments within the decades following their construction as well as their subsequent reuse in later centuries. In other words, many inscribed and sculpted stones have had multiple phases of activity written on to them during the early Middle Ages, whilst others reveal their biographies through their incorporation into new contexts.

It is clear that there is potential in considering short-term cycles of use and reuse alongside long-lasting biographies. For example, a 'short'-term life might be interpreted for five or six examples of cross-slabs in south-west Wales, where possibly seventh- to ninth-century cross motifs were added to monuments with earlier ogham and/or Roman inscriptions (Edwards 2007b, 47). In some cases these crosses respect earlier inscriptions, whilst in others they obliterate parts of them (Edwards 2007b, 48). Similarly, Clarke (2007) has 
highlighted several examples of Class I (fifth- to seventh-century AD) Pictish symbol stones with multiple sets of symbols, sometimes overwriting existing symbol motifs. In both these cases, these were stones that can be raised, moved and reactivated through a series of stages in their early medieval life-histories (see also Williams 2007; Gondek, this vol.).

In a seminal study of the cultural biographies of early medieval stone monuments, Burström (1996) explored the Viking-period reuse of picture stones within mortuary contexts. Picture stones of various dates were reused in stone kerbs and as head and footstones within cists at the Viking cemetery at Ihre, Hellvi parish (Burström 1996, 23-5). Burström argues that the picture stone reused above the female burial was at least one hundred years old when buried. Bearing a ship and woman with a drinking horn, the stone was placed face-down as the covering slab of the inhumation grave. When reused, the slab may have been a meaningful addition, its scene speaking to the dead at a time of Christian conversion and rapid socio-economic change. Rundkvist $(2012,146-7)$ has revisited this phenomenon and demonstrates that, like the picture stones and runestones of the Lake Mälar area, the Vendel Period (AD 540-790) saw the systematic destruction of the preceding era's picture stones on Gotland. Moreover, he identifies no further reuse within the Vendel or early Viking period and identifies the reuse recognized by Burström as an exclusively late Viking-period phenomenon (tenth and eleventh centuries). Significantly, the pattern is for the reuse of picture stones in male-gendered graves, reflecting the overall trend for male graves to receive structural elaborations (Rundkvist 2012, 148), and an association with sites where pagan cult was continuing, evidenced by furnished burial and the persistence of cremation and north-south-aligned inhumation. Hence, in this case, the reuse of picture stones might indeed reflect tensions over religious and social change in these centuries.

The biographical theme is widely addressed within the volume. The biography of place is considered by Kirton, Back Danielsson and O'Leary with contrasting data-sets and approaches. Meanwhile, Gondek focuses specifically on the use and reuse of Pictish symbol stones in settlement contexts. Crouwers considers not only the life-histories of Norwegian stone crosses but also the reuse of prehistoric sites where they were installed. Hall explores the different cultural biographies of stone monuments in Scotland over the longer term, while Ní Ghrádaigh explores the historical evidence of the twelfth-century reception of early medieval stone monuments. Williams' study overtly avoids considering the biography of hogback stones, but instead gives attention to the citations between monuments and media which informed their significance for their designers and audiences during the early Middle Ages.

\section{Landscape}

Early medieval scholars have long recognized that landscapes and monuments are inseparable and cannot be explored alone (e.g. Orton 2006). However, a 'landscape approach' to early medieval stone monuments might mean very different things in practice. Key to the approach is contextualizing the monument in a 'populated' setting where older and contemporary settlements, sites and monuments and the natural topography are recognized as agents in how monuments were located and engaged with. In general, the landscape context of English stone monuments has been less explored than that in other parts of Britain and Ireland and in Scandinavia. In part this is related to the fact 
that the corpus here has perhaps suffered most greatly in terms of movement from original locations and destruction (e.g. O'Sullivan 2011). In areas where original contexts are marginally better preserved, such as Wales, Scotland, Ireland and across Scandinavia, wider landscape contexts of individual monuments and groups of monuments have been discussed, particularly with relation to socio-political and ideological boundaries and sacred landscapes (e.g. Edwards 2001a and b; Gondek 2006 a and b; 2007; Turner 2006). Sometimes these wider landscape discussions result in spatial considerations of 'schools' or groups of monuments, such as the Govan School (e.g. Driscoll et al. 2005; Sidebottom 1994), which emphasize the collective power of monuments to promote social memory across considerable distances.

A key challenge in landscape studies of early medieval monuments is a lack of direct investigation into the archaeological contexts of early medieval stone monuments through landscape-centred fieldwork and largescale excavations at monument sites (as opposed to keyhole excavation at the base of monuments). This imbalance is beginning to be addressed by work that has looked at different scales of spatial context for early medieval stone monuments (see James 2005; Griffiths 2006; Gondek and Noble 2010).

Drawing from theoretical approaches adapted in prehistory to the study of the experience of landscape, there is also potential to move beyond map-based studies of monument distributions to consider the embodied experience of encountering stone monuments in the early medieval landscape. Here, micro-topographical approaches, looking at the spatial interplay of sculpture with church sites and settlements, have potential (Gondek, this vol.; Gondek and Noble 2010), as does considering how stone monuments operated within the mortuary arena (Williams 2006; Devlin 2011) and along routes and tracks. For example, T. Ó Carragáin (2009) examines the role of stone monuments - leachta - and the form and decoration of stone crosses surmounting them, within the pilgrimage landscape of Inishmurray, Co. Sligo, the origins of which are taken back at least to the ninth and tenth centuries $A D$ and are argued to have contained Eucharistic celebrations. Hence, crosses were 'stage props': stations during penitential processions (T. Ó Carragáin 2009, 215-16). Ó Carragáin likens the landscape of memory on Inishmurray to that documented for St Davids and discussed by Heather James, where wells, burial grounds and chapels of late medieval date, but possibly with earlier origins (James 1993), were connected with particular miracles and moments in the lives of saints. This spatializing of the cult across processional routes embellished with stone monuments might be considered as forming evolving and varied, but significant, elements of many early medieval monastic centres and their hinterlands.

This leads us to consider the wider study of landscape dynamics of routes, boundaries and ancient monuments in the study of monument location, as advocated by Williams (1999; 2011b; Williams et al. 2010; Kirton 2015; this vol.). Rarely do we have the dense concentrations of monuments that allow the detailed reconstructions of church organization on a landscape scale equivalent to that discussed by T. Ó Carragáin (2003) for Iveragh and Dingle or the dense concentration of rune-stones in the landscape of Täby, Uppland. Yet it is evident that conventional mapping needs to be married to a more qualitative, subjective engagement with topography; the combination of thick description and control samples can allow for new insights into why and how early medieval stone monuments were situated where they were and, equally importantly, the reasons behind 
where they were not situated (see Williams 1999; Williams et al. 2010). Here, Carver's (2004, 26-8) approach to how the Tarbat peninsula monuments may have interacted with the Portmahomack monastery in relation to landscape and seascape is very revealing.

Despite these approaches, a clear theoretical context for approaching the landscape contexts of early medieval stone monuments is often lacking. Indeed, those studies of the landscape contexts of Anglo-Saxon monuments have principally focused on cemeteries and burial mounds, without adequate discussions of inscribed and sculpted stone monuments (e.g. Semple 1998; 2003; Williams 1999; 2006), although their approach is readily applicable to many stone monuments, as can be seen from ongoing research exploring the landscape context of the Pillar of Eliseg (see Williams 2011b).

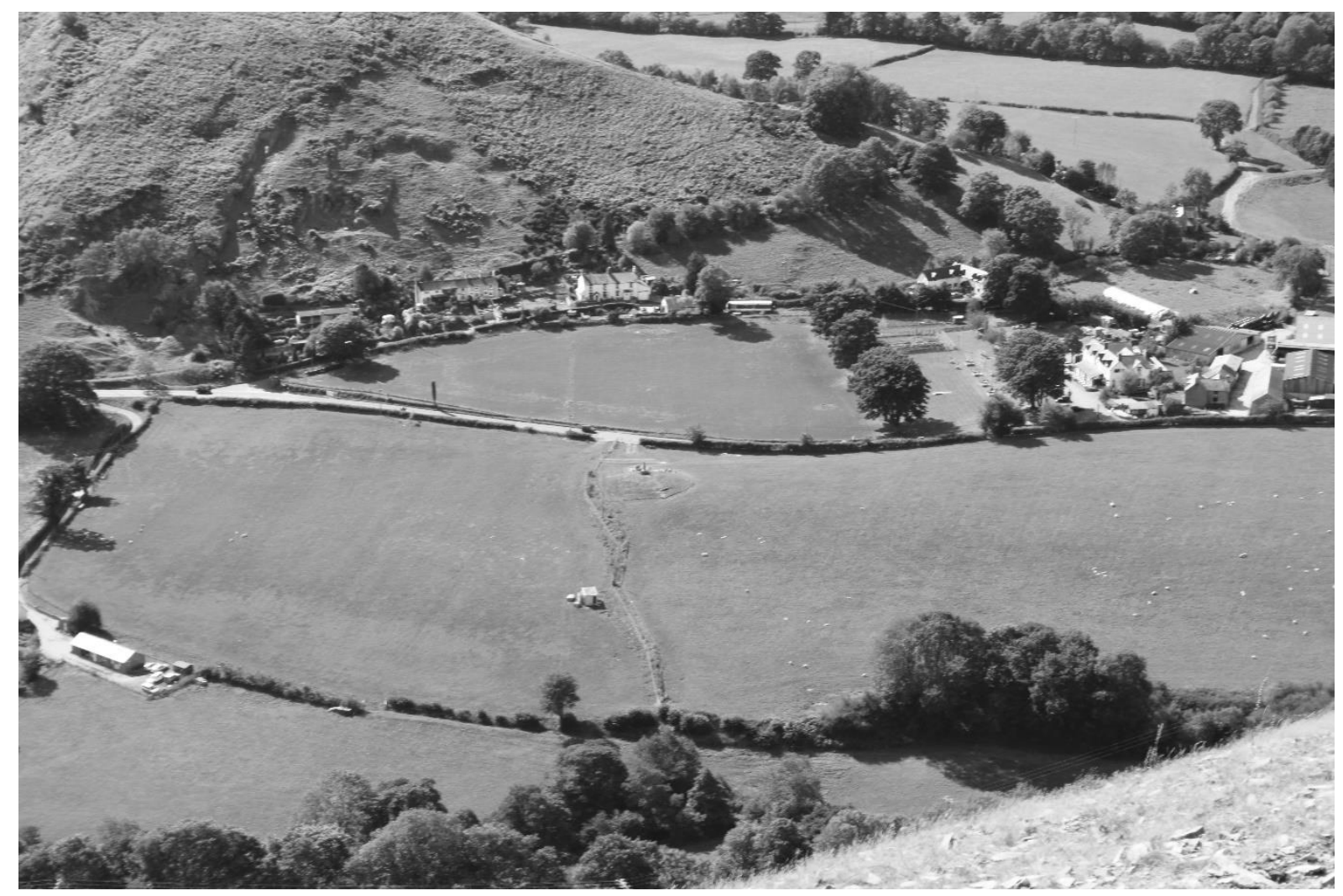

Fig. 1.5 The Pillar of Eliseg in its modern landscape context, viewed from hills to the east. The cross was located on a far-earlier Bronze Age burial monument on a spur of land with a plateau of flat ground to its north and west.

The Pillar of Eliseg is also a good example of how the excavation of the immediate setting of an early medieval stone monument can enhance our knowledge of its biography and landscape significance is the recent fieldwork around the early ninth-century 'Pillar of Eliseg' (Figs 1.5 and 1.6). Excavations between 2010 and 2012 revealed details of a multiphased prehistoric cairn containing many secondary cist-graves upon which the monument is now, and quite possibly was originally, raised. Excavations also revealed details of aspects of the monument's subsequent biography, including its rehabilitation in the late eighteenth century. Moreover, the fieldwork has enhanced our understanding of the topographical setting of the cross in the early medieval landscape as a landmark along routes and possibly a site of assembly on a plateau within the valley, with striking acoustics created by the 
surrounding hills (Edwards 2009; Williams 2011b). Like Maen Achwyfan but a century earlier, the Pillar was a place of memory and assembly in the early medieval landscape.

For another example we can turn to the Baltic. Gotlandic picture stones depict movement by horse and ship as integral to their iconography and have been argued by some to be symbolic doorways to the afterlife (e.g. Andrén 1993). Their landscape context has, therefore, long been seen as important, although few are conclusively in their original location. Andreeff (2012) has recently excavated around the picture stone at Fröjel Stenstugu, Gotland. Thought to be in situ, the monument was located next to a road marked out on an eighteenth-century map which runs along a raised shingle beach ridge: a natural and perhaps ancient artery of communication. The parish boundary between Klinte and Fröjel is also close by. Twenty-seven square metres were excavated around the monument, revealing the ancient line of the road and a cremation burial of at least two individuals radiocarbon dated to the seventh to ninth centuries AD. Andreeff suggests that the cremation burial and picture stone were part of the same funerary process (Andreeff 2012, 135).

A number of papers address the landscape theme in this book. Ni Ghrádaigh and O'Leary consider the power of place from literary and archaeological perspectives respectively. Gondek explores how stone monuments operated within the micro-landscapes of settlement sites and their environs. For the wider landscape perspective, Back Danielsson considers Scandinavian rune-stones in terms of embodied engagement. Likewise, Kirton's study of the Cleulow Cross makes a clear argument for why the cross is where it is; like the Pillar of Eliseg and Maen Awyfan, the Cleulow cross was situated to be seen from and to be seen.

\section{Conclusion}

Most studies of early medieval stone monuments focus on their date, distribution, iconography, meaning and context. This volume is both optimistic and original in drawing together scholars who wish to explore new trajectories of theory to investigate how momuments operated and created social memories. During construction and once erected, stone monuments were implicated in complex and shifting processes of use and reuse in evolving ritual and social practices within inhabited landscapes that were changing rapidly with each generation in terms of population density, routes, settlement patterns and territorial organization. Thus, in considering the materialities, biographies and landscape contexts of early medieval stone monuments we hope to better understand how stone monuments created and transformed memory and were enmeshed in the making and remaking of social and religious worlds.

The following contributions foreground the practical and performative constitution of memory - memory work - revealed through the study of early medieval stone monuments. We consider the construction process as memory work in itself, involving different agents (i.e. patrons, carvers and sculptors) and different audiences. Stone monuments were multisensual material cultures, both visual and tactile, associated with particular sounds and perhaps also aromas, tastes, bodily engagements and experiences. 


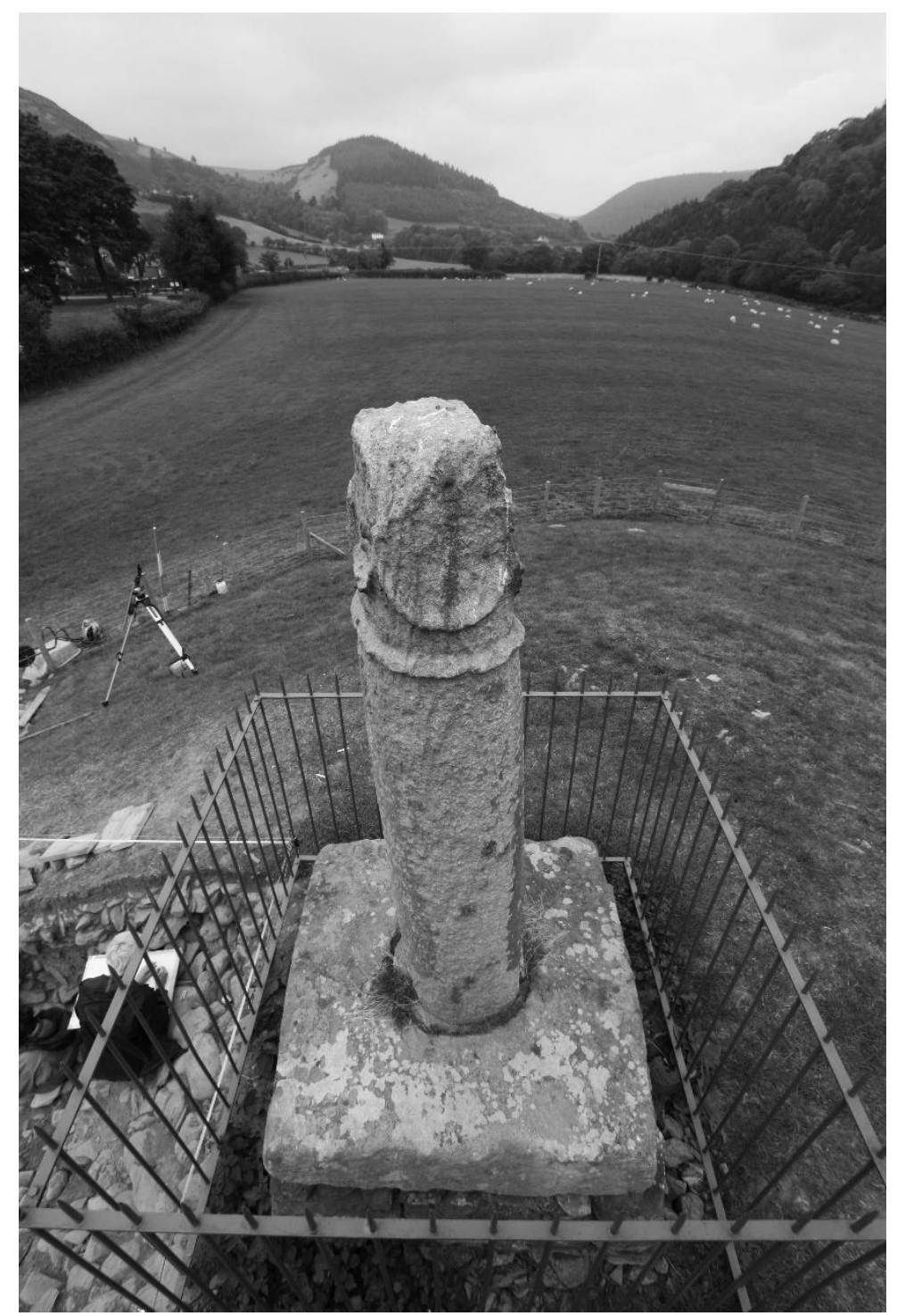

Fig. 1.6 The Pillar of Eliseg looking north during excavations in 2011 by Project Eliseg. Behind the ninth-century cross-shaft is a plateau that had to be traversed by those navigating the Horseshoe Pass or World's End en route from the north-west or north-east.

This introduction has deliberately foregrounded Welsh examples to complement the case studies of the collection in other parts of Britain as well as in Ireland and Scandinavia. The geographical parameters reflect both the interests and expertise of the editors and also the emerging vibrancy of interdisciplinary endeavours of scholars working on different parts of the Islands of the North Atlantic and Fennoscandia in the study of the materialities, biographies and landscapes of early medieval stone monuments. However, the strength of this collection is in its themes, not its geographical foci. Together, the chapters in this book set a new framework for exploring how these fragmented and intriguing traces of early medieval communities can be explored with new vigour and confidence throughout the archipelago of Britain and Ireland, Scandinavia and further afield throughout Atlantic Europe and the Mediterranean, not only in the regions considered in this book. 


\section{Acknowledgements}

The authors thank Ing-Marie Back Danielsson, Mark Hall, Andrew Meirion Jones, Anna Mackenzie, Adrián Maldonado, Clíodhna O'Leary, Ruth Nugent and Victoria Whitworth for constructive and insightful comments and suggestions on drafts of this chapter. Special thanks to Adrián Maldonado for his observations on the cross at Maen Achwyfan.

Bibliography

Alcock, S. 2002. Archaeologies of the Greek Past: Landscape, Monuments, and Memories, Cambridge: Cambridge University Press

Allen, J. and Anderson, J. 1903 (1993 reprint). Early Christian Monuments of Scotland, Balgavies: Pinkfoot Press

Andrén, A. 1993. Doors to other worlds: Scandinavian death rituals in Gotlandic perspectives, Journal of European Archaeology, 1, 33-56

Andrén, A. 2000. Re-reading embodied texts - an interpretation of runestones, Current Swedish Archaeology, 8, 7-31

Andreeff, A. 2012. Archaeological excavations at picture stone sites, in Karnell (ed.), 129-50

Bailey, R. N. 1996. England's Earliest Sculptors, Toronto: Pontifical Institute of Medieval Studies

Bailey, R. 2011. Corpus of Anglo-Saxon Stone Sculpture Volume IX: Cheshire and Lancashire, Oxford: Oxford University Press

Bidwell, P. 2010. A survey of the Anglo-Saxon crypt at Hexham and its reuse of Roman stonework, Archaeologia Aeliana, XXXIX, 53-145

Boric, D. (ed.) 2010. Archaeology and Memory, Oxford: Oxbow

Bradley, R. 1987. Time regained: the creation of continuity, Journal of the British Archaeological Association, 140, 1-17

Bradley, R. 2002. The Past in Prehistoric Societies, London: Routledge

Bradley, R. and Williams, H. (eds) 1998. The Past in the Past: The Reuse of Ancient Monuments, World Archaeology, 30(1)

Brate, E. 1911. Ostergotlands runinskrifter transkate och tolkade, Sveriges Runinskrifter, 2, Stockholm: KVHAA

Brate, E. and Wessén, E. 1936. Sodermanlands runinskrifter granskade och tolkade, Sveriges Runinskrifter, 3, Stockholm: KVHAA 
Burström, M. 1996. Other generations' interpretation and use of the past: the case of the picture stones on Gotland, Current Swedish Archaeology, 4, 21-40

Burström, M. 2012. Treasured Memories: Tales of Buried Belongings in Wartime Estonia, Lund: Nordic Academic Press

Caple, C. 2010. Ancestor artefacts - ancestor materials, Oxford Journal of Archaeology, 29(3), 305-18

Carver, M. 2001. Why that? Why there? Why then? The politics of early medieval monumentality, in $\mathrm{H}$. Hamerow and A. MacGregor (eds), Image and Power in the Archaeology of Early Medieval Britain, 1-22, Oxford: Oxbow

Carver, M. (ed.) 2003. The Cross Goes North: Processes of Conversion in Northern Europe, AD 300-1300, York: York Medieval Press Carver, M. 2004. An lona of the east: the earlymedieval monastery at Portmahomack, Tarbat Ness, Medieval Archaeology, 48, 1-30

Carver, M. 2005. Sculpture in action: contexts for the stone carving on the Tarbat peninsula, Easter Ross, in S. M. Foster and M. Cross (eds), Able Minds and Practised Hands: Scotland's Early Medieval Sculpture in the 21st century, 13-36, The Society for Medieval Archaeology Monograph 23. Leeds: Maney

Cassidy, B. 1992. The later life of the Ruthwell cross: from the seventeenth century to the present, in B. Cassidy (ed.), The Ruthwell Cross, 3-47, Princeton: Index of Christian Art, Department of Art and Archaeology, Princeton University

Clarke, D. 2007. Reading the multiple lives of Pictish symbol stones, Medieval Archaeology, $51,19-40$

Collingwood, W. 1927. Northumbrian Crosses of the Pre-Norman Age, London: Faber and Gwyer

Craig, D. 1991. Pre-Norman sculpture in Galloway: some territorial implications, in R. Oram and G. Stell (eds), Galloway Land and Lordship, 45-62, Edinburgh, Society for Northern Studies

Cramp, R. 1984. Corpus of Anglo-Saxon Stone Sculpture Volume I: County Durham and Northumberland, 2 vols, Oxford: Oxford University Press

Cramp, R. 1993. A reconsideration of the monastic site of Whitby, in R. M. Spearman and J. Higgitt (eds), The Age of Migrating Ideas: Early Medieval Art in Northern Britain and Ireland, 64-73, Edinburgh and Stroud: National Museum of Scotland and Sutton

Cramp, R. 2006. Corpus of Anglo-Saxon Stone Sculpture Volume VII: South-West England, Oxford: Oxford University Press 
Cramp, R. 2010. New directions in the study of Anglo-Saxon sculpture, Transactions of the Leicestershire Archaeological and Historical Society, 84, 1-25

Cummings, V. 2002. Experiencing texture and transformation in the British Neolithic, Oxford Journal of Archaeology, 21(3), 249-61

Devlin, Z. 2007. Remembering the Dead in Anglo-Saxon England: Memory Theory in Archaeology and History, Oxford: British Archaeological Research Reports, British Series, 446

Devlin, Z. 2011. Putting memory in its place: sculpture, cemetery topography and commemoration, in M. F. Reed (ed.), New Voices on Early Medieval Sculpture in Britain and Ireland, 32-41, Oxford: British Archaeological Reports, British Series, 542

Driscoll, S. 1998. Picts and prehistory: cultural resource management in early medieval Scotland, World Archaeology, 30(1), 142-58

Driscoll, S. 2000. Christian monumental sculpture and ethnic expression in early Scotland, in W. O. Frazer and A. Tyrell (eds), Social Identity in Early Medieval Britain, 233-52, Leicester: Leicester University Press

Driscoll, S., O'Grady, O. and Forsyth, K. 2005. The Govern School revisited: searching for meaning in the early medieval sculpture of Strathclyde, in Foster and Cross (eds), 135-58

Eckardt, H. and Williams, H. 2003. Objects without a past? The use of Roman objects in early Anglo-Saxon graves, in Williams (ed.), 141-70

Edwards, N. 1999. Viking-influences sculpture in North Wales: its ornament and context, Church Archaeology, 3, 5-16

Edwards, N. 2001a. Monuments in a landscape: the early medieval sculpture of St David's, in $\mathrm{H}$. Hamerow and A. MacGregor (eds), Image and Power in the Archaeology of Early Medieval Britain, 53-77, Oxford: Oxbow

Edwards, N. 2001b. Early medieval inscribed stones and stone sculpture in Wales: context and function, Medieval Archaeology, 45, 15-39

Edwards, N. 2007a. Early medieval sculpture in south-west Wales: the Irish Sea connection, in Moss (ed.), 184-97

Edwards, N. 2007b. A Corpus of Early Medieval Inscribed Stones and Stone Sculpture in Wales. Volume II, South-West Wales, Cardiff: University of Wales Press

Edwards, N. 2009. Rethinking the Pillar of Eliseg, Antiquaries Journal, 89, 143-77

Edwards, N. 2013. A Corpus of Early Medieval Inscribed Stones and Stone Sculpture in Wales. Volume III, North Wales, Cardiff: University of Wales Press 
Eaton, T. 2000. Plundering the Past: Roman Stonework in Medieval Britain, Stroud: Tempus

Everson, P. and Stocker, D. 1999. Corpus of Anglo-Saxon Stone Sculpture Volume V: Lincolnshire, Oxford: Oxford University Press

Filmer-Sankey, W. 1996. The 'Roman Emperor' in the Sutton Hoo ship burial, Journal of the British Archaeological Association, 149, 1-9

Fisher, I. 2001 Early Medieval Sculpture in the West Highlands and Islands, Edinburgh: RCAH MS and the Society of Antiquaries of Scotland

Foster, S. and Cross, M. (eds) 2004. Able Minds and Practised Hands: Scotland's Early Medieval Sculpture in the 21st Century, Leeds: Maney

Foster, S. 2014. Circulating agency: the $\mathrm{V}$ and $\mathrm{A}$, Scotland and the multiplication of plaster coasts of 'Celtic crosses', Journal of the History of Collections. doi: 10.1097/jch/fhuoo8

Gell, A. 1992. The technology of enchantment and the enchantment of technology, in J. Coote and A. Shelton (eds), Anthropology: Art and Aesthetics, 40-67, Oxford: Clarendon

Giles, K. 2007. Seeing and believing: visuality and space in pre-modern England, World Archaeology, 39(1), 105-21

Gondek, M. 2006a. Investing in sculpture: power in early historic Scotland, Medieval Archaeology, 50, 105-42

Gondek, M. 2006b Early historic sculpture and landscape: a case study of Cladh a'Bhile, Ellary, Mid-Argyll, Proceedings of the Society of Antiquaries of Scotland, 138, 237-58

Gondek, M. 2007. Pictish symbol stones: caught between prehistory and history, in A. Mazel, G. Nash and C. Waddington (eds), Art as Metaphor: The Prehistoric Rock-art of Britain, 69-89, Oxford: Archaeopress

Gondek, M. 2010. Constructing sacred space - soil, stone, water and symbols: early medieval carved stone monuments from Tillytarmot, Aberdeenshire, in A. George, D. Hawley, G. Nash, J. Swann and L. White (eds), Early Medieval Enquiries: The Proceedings of the Clifton Antiquarian Club, 9, 318-33, Bristol: Clifton Antiquarian Club

Gondek, M. and Noble, G. 2010. Together as one: the landscape of the symbol stones at Rhynie, Aberdeenshire, in S. Driscoll, J. Geddes and M. Hall (eds), Pictish Progress: Pictish Studies for the 21st Century, 281-306, Leiden: Brill

Gosden, C. 2005. What do objects want? Journal of Archaeological Method and Theory, 12, 193-211 
Gosden, C. and Marshall, Y. 1999. The cultural biography of objects, World Archaeology, $31(2), 169-78$

Griffiths, D. 2006. Maen Achwyfan and the context of Viking settlement in north-east Wales, Archaeologia Cambrensis, 155, 143-62

Hall, M. A. 2012. Three stones, one landscape, many stories. Cultural biography and the early medieval scuptures of Inchyra and St Madoes, Carse of Gowrie, Perthshire, Scotland, in S. H. Dudley, A. J. Barnes, J. Binnie, J. Petrov and J. Walklate (eds), Narrating Objects, Collecting Stories: Essays in Honour of Professor Susan M. Pearce, 85-102, London: Routledge

Hall, M. A. 2013. Performing prehistory in early medieval Scotland: making sense of the meanings of masks on Pictish sculpture, in H. Meller and R. Maraszek (eds), 2012 Masken der Vorzeit in Europa [II], International Tagung vom 19. Bis 21. November 2010 in Hall (Saale), Tagungen Landesmuseum für Vorgeschichte Halle (Saale), 7, 93-110, Halle: Landesamt für Denkmalpflege und Archäologie Sachsen-Anhalt, Landesmuseum für Vorgeschichte

Hall, M. A., Forsyth, K., Henderson, I., Scott, I. G., Trench-Jellicoe, R. and Watson, A. 2000. Of makings and meanings: towards a cultural biography of the Crieff Burgh Cross, Strathearn Perthshire', Tayside and Fife Archaeological Journal, 6, 154-88

Hamerow, H, Hinton, D. and Crawford, S. (eds) 2011. The Oxford Handbook of Anglo-Saxon Archaeology, Oxford: Oxford University Press

Harbison, P. 1992. The High Crosses of Ireland vol.1 and 2, Dr. Rudolf Habelt GMBH, Bonn

Hawkes, J. 2002. The Sandbach Crosses: Sign and Significance in Anglo-Saxon Sculpture, Dublin: Four Courts Press.

Hawkes, J. 2003a. Reading stone, in C. E. Karkov and F. Orton (eds), Theorizing Anglo-Saxon Stone Sculpture, 5-30, Morgantown: West Virginia University Press

Hawkes, J. 2003b. luxta Morem Romanorum: Stone and Sculpture in Anglo-Saxon England, in C. E. Karkov and G. H. Brown (eds), Anglo- Saxon Styles, 69-100, Albany: State University of New York

Hawkes, J. 2007. Collingwood and Anglo-Saxon sculpture: art history or archaeology? in Moss (ed.) 142-52

Henderson, G. and Henderson, I. 2004. The Art of the Picts. Sculpture and Metalwork in Early Medieval Scotland, London: Thames and Hudson

Henry, F. 1964. Irish High Crosses, Cultural Relations Committee, Dublin

Henry, F. 1965. Irish Art in the Early Christian Period, London: Metheun 
Higgitt, J. (ed.) 1986. Early Medieval Sculpture in Britain and Ireland, BAR, Oxford

Higgitt, J. 1997. Early medieval inscriptions in Britain and Ireland and their audiences, in D. Henry (ed.), The World, the Germ and the Thorn: Pictish and Related Studies Presented to Isabel Henderson, 67-78, Angus: Pinkfoot

Higgitt, J. 2003. Design and meaning in early medieval inscriptions in Britain and Ireland, in Carver (ed.), 327-38

Higham, N. and Ryan, M. 2013. The Anglo-Saxon World, New Haven: Yale University Press

Hingley, R. 2012. Hadrian's Wall: A Life, Oxford: Oxford University Press

Holtorf, C. 1996. Towards a chronology of megaliths: understanding monumental time and cultural memory, Journal of European Archaeology, 4, 119-52

Ingold, T. 2007. Materials against materiality, Archaeological Dialogues, 14, $1-16$

Jackson, H. 2007. Geological sources and selection of stone, in Edwards 2007, 19-29

James, H. 1993. The cult of St David in the Middle Ages, in M. Carver (ed.), In Search of Cult, Archaeological Investigations in Honour of Philip Rahtz, 105-12, Woodbridge: Boydell

James, H. 2005. Pictish cross-slabs: an examination of their original archaeological context, in Foster and Cross (eds), 95-112

James, H., Henderson, I., Foster, S. and Jones, S. 2008. A Fragmented Masterpiece: Recovering the Biography of the Hilton of Cadboll Pictish Cross-Slab, Edinburgh: Society of Antiquaries of Scotland

Jansson, S. B. F. (trans. P. Foote). 1987. Runes in Sweden, Stockholm: Gidlunds

Jones, A. 1999. Local colour: megalithic architecture and colour symbolism in Neolithic Arran, Oxford Journal of Archaeology, 18(4), 339-50

Jones, A. 2003. Technologies of remembrance: memory, materiality and identity in Early Bronze Age Scotland, in Williams (ed.), 65-88

Jones, A. 2004. Archaeometry and materiality: materials based analysis in theory and practice, Archaeometry, 46(3), 327-38

Jones, A. 2007. Memory and Material Culture, Cambridge: Cambridge University Press

Joy, J. 2009. Reinvigorating object biography: reproducing the drama of object lives, World Archaeology, 41(4), 540-56 
Karkov, C. 2011. The Art of Anglo-Saxon England. Woodbridge: Boydell.

Karnell, M. H. (ed.) 2012. Gotland's Picture Stones: Bearers of an Enigmatic Legacy, Gotlädskt Arkiv, Reports from the Friends of the Historical Museum Association, 84, Visby: Gotlands Museum

Kelly, D. 1991. The heart of the matter: models for Irish High Crosses, Journal of the Royal Society of Antiquaries of Ireland, 121, 105-45

Kirton, J. 2015. Sculpture and Place: A Biographical Approach to Recontextualizing Cheshire's Early Medieval Stone Sculpture, unpublished PhD thesis, University of Chester

Llillios, K. T. and Tasamis, V. 2010. Material Mnemonics: Everyday Memory in Prehistoric Europe, Oxford: Oxbow

Macalister, R. 1945. Corpus Inscriptionum Insularum Celticarum Vol. 2, Stationary Office, Dublin

MacLean, D. 1997. King Oswald's wooden cross at Heavenfield in context, in C. E. Karkov, M. Ryan and R. T. Farrell (eds), The Insular Tradition, 79-97, Albany: State University of New York Press

Maddern, C. 2013. Raising the Dead: Early Medieval Name Stones in Northumbria, Turnhout: Brepols

McClain, A. 2011. Local churches and the conquest of the north: elite patronage and identity in Saxo-Norman Northumbria, in D. Petts and S. Turner (eds), Early Medieval Northumbria: Kingdoms and Communities, AD 450-1100, Turnhout: Brepols, Studies in the Early Middle Ages, 24

Mills, B. 2009. From the ground up. Depositional history, memory and materiality, Archaeological Dialogues, 16(1), 38-40

Mills, B. and Walker, W. H. (eds) 2008. Archaeologies of Material Practices, Sante Fe: School for Advanced Research Advanced Seminar Series.

Moreland, J. 1999. The world(s) of the cross, World Archaeology, 31(2), 194-213

Moreland, J. 2001. Archaeology and Text, London: Duckworth

Moss, R. (ed.) 2007. Making and Meaning in Insular Art, Dublin: Four Courts Press

Mytum, H. 2003/2004. Artefact biography as an approach to material culture: Irish gravestones as a material form of genealogy, Journal of Irish Archaeology, 12/13, 111-27

Nash-Williams, V. E. 1950 Early Christian Monuments of Wales, Cardiff: HMSO 
Ní Ghrádaigh, J. and Mullins, J. 2013. Apostolically inscribed: St Cuthbert's coffin as sacred vessel, in J. Ashbee and J. Luxford (eds), Medieval Art and Architecture in Newcastle and Northumberland, 73-89, British Archaeological Association Transactions Series, 36, Leeds: Maney

Okasha, E. 2003. Spaces between words: word separation in Anglo-Saxon inscriptions, in Carver (ed.), 339-50

Orton, F. 2003. Rethinking the Ruthwell and Bewcastle monuments: some deprecation of style; some consideration of form and ideology, in C. E. Karkov and G. H. Brown (eds), Anglo-Saxon Styles, 31-68, Albany: State University of New York Press

Orton, F. 2006. At the Bewcastle monument, in place, in C. A. Lees and G. R. Overing (eds), A Place to Believe in: Locating Medieval Landscapes, 29-66, University Park: Pennsylvania State University Press

Orton, F., Wood, I. and Lees, C. 2007. Fragments from History: Rethinking the Ruthwell and Bewcastle Monuments, Manchester: Manchester University Press

Ó Carragáin, É. 1999. The Necessary Distance: Imitatio Romae and the Ruthwell Cross, in J. Hawkes and S. Mills (eds), Northumbria's Golden Age, 315-26, Stroud: Sutton

Ó Carragáin, É. 2003. Between Annunciation and Visitation: spiritual birth and the cycles of the sun on the Ruthwell Cross: a response to Fred Orton, in C. E. Karkov and F. Orton (eds), Theorizing Anglo-Saxon Stone Sculpture, 131-87, Morgantown: West Virginia University Press

Ó Carragáin, T. 2003. A landscape converted: archaeology and early church organization on Iveragh and Dingle, Ireland, in Carver (ed.), 127-52

Ó Carragáin, T. 2007. Skeumorphs and spolia: the presence of the past in Irish preRomanesque architecture, in Moss (ed.), 95-109

Ó Carragáin, T. 2009. The saint and the sacred centre: the early medieval pilgrimage landscape of Inishmurray, in N. Edwards (ed.), The Archaeology of the Early Medieval Celtic Churches, Society for Medieval Archaeology Monograph 29, Society for Church Archaeology Monograph 1, 207-26, Leeds: Maney

O'Connor, B. and Cooney, G. 2009. Introduction: materialitas and the significance of stone, in B. O'Connor, G. Cooney and J. Chapman (eds), Materialitas: Working Stone, Carving Identity, Prehistoric Society Research Paper, 3, 1-9, Oxford: Oxbow

O'Connor, B., Cooney, G. and Chapman, J. (eds) 2009. Materialitas: Working Stone, Carving Identity, Oxford: Oxbow 
O'Sullivan, D. 2011. Normanising the North: The evidence of Anglo-Saxon and AngloScadninavian Sculpture, Medieval Archaeology, 55, 163-91

Netzer, N. 1999 The Book of Durrow: the Northumbrian connection, in J. Hawkes and S. Mills (eds), Northumbria's Golden Age, Stroud: Sutton, 315-26.

Petts, D. 2002. The reuse of prehistoric standing stones in Western Britain? A critical consideration of an aspect of early medieval monument reuse, Oxford Journal of Archaeology, 21(2), 195-209

Petts, D. 2007. De Situ Brecheniauc and Englunion y Beddau: Writing about burial in early medieval Wales, in S. Semple and H. Williams (eds), Early Medieval Mortuary Practices, Anglo-Saxon Studies in Archaeology and History, 14, 163-72, Oxford: Oxford University School of Archaeology

Pirotte, E. 2001. Hidden order, order revealed: new light on carpet-pages, in M. Redknap, N. Edwards, S. Youngs, A. Lane and J. Knight (eds), Pattern and Purpose in Insular Art, 2037, Oxford: Oxbow

Ritchie, A. (ed.) 1994 Govan and its Early Medieval Sculpture, Alan Sutton, Stroud.

Rodwell, W., Hawkes, J., Howe, E. and Cramp, R. 2008. The Lichfield Angel: a spectacular Anglo-Saxon painted sculpture, Antiquaries Journal, 88, 48-108

Rundkvist, M. 2012. The secondary use of picture stones on Gotland prior to the first stone churches, with a typology of picture stone outline shapes, in Karnell (ed.), 145-60

Sanmark, A. 2008. Administrative organization and state formation: a case study of assembly sites in Södermanland, Sweden, Medieval Archaeology, 53, 205-41

Sanmark, A. and Semple, S. 2008. Places of assembly: new discoveries in Sweden and England, Fornvannen, 103(4), 245-59

Saunders, N. 2007. Killing Time: the Archaeology of the First World War, Stroud: Sutton

Sawyer, B. 2001. The Viking Age Rune-Stones, Oxford: Oxford University Press.

Scarre, C. 2004. Displaying the stones: the materiality of 'megalithic' monuments, in E. DeMarrais, C. Gosden and C. Renfrew (eds), Rethinking Materiality: the Engagement of Mind with the Material World, 141-52, Cambridge: McDonald Institute for Archaeological Research

Semple, S. 1998. A fear of the past: the place of the prehistoric burial mound in the ideology of middle and later Anglo-Saxon England, World Archaeology, 30(1), 109-26 
Semple, S. 2003. Burials and political boundaries in the Avebury region, North Wiltshire, in D. Griffiths, A. Reynolds and S. Semple (eds), Boundaries in Early Medieval Britain, AngloSaxon Studies in Archaeology and History, 12, 72-91, Oxford: Oxford University School of Archaeology

Semple, S. 2013. Perceptions of the Prehistoric in Anglo-Saxon England: Religion, Ritual and Rulership in the Landscape, Oxford: Oxford University Press

Sharpe, R. (trans.) 1995. Adomnan of Iona, Life of Columba, London: Harmondsworth

Sherley-Price, L. (trans.) 1990. Bede: Ecclesiastical History of the English People with Bede's Letter to Egbert and Cuthbert's Letter on the Death of Bede, revised edition, London: Penguin

Sidebottom, P. 1994. Schools of Anglo-Saxon Stone Sculpture in the North Midlands, unpublished PhD thesis, University of Sheffield

Stocker, D. 2000. Monuments and merchants: irregularities in the distribution of stone sculpture in Lincolnshire and Yorkshire in the tenth century, in D. M. Hadley and J. D. Richards (eds), Cultures in Contact: Scandinavian Settlement in England in the Ninth and Tenth Centuries, 179-212, Turnhout: Brepols

Stocker, D. with Everson, P. 1990. Rubbish recycled: A study of the re-use of stone in Lincolnshire, in D. Parsons (ed.), Stone: Quarrying an Building in England, 83-101, Chichester: Phillimore

Stuart, J. (ed.) 1867. Sculptured Stones of Scotland, Aberdeen: Spaulding Club

Swift, E. 2006. Object biography, re-use and recycling in the Late to Post-Roman transition period and beyond: rings made from Romano-British bracelets, Britannia, 43, 1-49

Tarlow, S. 1999. Bereavement and Commemoration, Oxford: Blackwell.

Thompson, V. 2003. Memory, salvation and ambiguity: a consideration of some AngloScandinavian grave-stones from York, in Williams (ed.), 215-26

Thompson, V. 2004. Dying and Death in Later Anglo-Saxon England, Woodbridge: Boydell

Turner, S. 2006. Making a Christian Landscape: The Countryside of Early Medieval Cornwall, Devon and Wessex, Exeter: University of Exeter Press.

Van Dyke, R. and Alcock, S. (eds) 2003. Archaeologies of Memory, Oxford: Blackwell.

Watson, A. and Keating, D. 1999. Architecture and sound: an acoustic analysis of megalithic monuments in prehistoric Britain, Antiquity, 73, 325-36

Webster, L. 2012. Anglo-Saxon Art: A New History, London: British Museum 
Wessén, E. and Jansson, S. B. F. 1943. Upplands runinskrifter, Sveriges Runinskrifter, 6, Uppsala: Almqvist and Wiksells

Williams, H. 1997. Ancient Landscapes and the dead: the reuse of prehistoric and Roman monuments as early Anglo-Saxon burial sites, Medieval Archaeology, 41, 1-31

Williams, H. 1999. Placing the dead: investigating the location of wealthy barrow burials in seventh century England, in M. Rundkvist (ed.), Grave Matters: Eight Studies of Burial Data from the first millennium AD from Crimea, Scandinavia and England, 57-86, Oxford: British Archaeological Report, International Series, 781

Williams, H. 2001. Death, memory and time: a consideration of mortuary practices at Sutton Hoo, in C. Humphrey and W. Ormrod (eds), Time in the Middle Ages, 35-71, York: York Medieval Press

Williams, H. (ed.) 2003. Archaeologies of Remembrance: Death and Memory in Past Societies, New York: Kluwer/Plenum

Williams, H. 2005. Keeping the dead at arm's length: memory, weaponry and early medieval mortuary technologies, Journal of Social Archaeology, 5(2), 253-75

Williams, H. 2006. Death and Memory in Early Medieval Britain, Cambridge: Cambridge University Press.

Williams, H. 2007. Depicting the dead: commemoration through cists, cairns and symbols in early medieval Britain, Cambridge Archaeological Journal, 17(2), 145-64

Williams, H. 2010. Engendered bodies and objects of memory in Final Phase graves, in J. Buckberry and A. Cherryson (eds), Burial in Later Anglo-Saxon England c. 650-1100 AD, 24-36, Oxford: Oxbow

Williams, H. 2011a. Cremation and present pasts: a contemporary archaeology of Swedish memory groves, Mortality, 16(2), 113-30

Williams, H. 2011b. Remembering elites: early medieval stone crosses as commemorative technologies, in L. Boye, P. Ethelberg, L. Heidemann Lutz, S. Kleingärtner, P. Kruse, L. Matthes and A. B. Sørensen (eds), Arkaologi i Slesvig/Archaologie in Schleswig. Sonderband 'Det 61. Internationale Sachsensymposion 2010' Haderslev, Denmark, 13-32, Neumünster: Wachholtz

Williams, H. 2011c. The sense of being seen: ocular effects at Sutton Hoo, Journal of Social Archaeology, 11(1), 99-121

Williams, H., Rundkvist, M. and Danielsson, A. 2010. The landscape of a Swedish boatgrave cemetery, Landscapes, 11(1), 1-24 
Wood, I. 2006. Constantinian crosses in Northumbria, in C. Karkov (ed.), The Place of the Cross in Anglo-Saxon England, 3-13, Woodbridge: Boydell

Yoffee, N. (ed.) 2007. Negotiating the Past in the Past: Identity, Memory, and Landscape in Archaeological Research, Tucson: University of Arizona Press 